\title{
Evaluation of the Pancreatoprotective Effect of Nannochloropsis oculata Extract against Streptozotocin-Induced Diabetes in Rats
}

\author{
Wael Mahmoud Aboulthana ${ }^{1 *}$, Amal Mohamed El-Feky², Noha El-Sayed Ibrahim³ ${ }^{3}$ Ram Kumar Sahu', \\ Abo El-Khair Badawy El-Sayed ${ }^{5}$ \\ ${ }^{1}$ Biochemistry Department, Genetic Engineering and Biotechnology Division, National Research Centre, Dokki, Giza, Egypt (Affiliation ID: 60014618). \\ ${ }^{2}$ Pharmacognosy Department, Pharmaceutical and Drug Industries Research Division, National Research Centre, Dokki, Giza, Egypt (Affiliation ID: \\ 60014618). \\ ${ }^{3}$ Microbial Biotechnology Department, Genetic Engineering and Biotechnology Division, National Research Centre, Dokki, Giza, Egypt (Affiliation ID: \\ 60014618). \\ ${ }^{4}$ Columbia Institute of Pharmacy, Tekari, Raipur (Chhattisgarh), India. \\ ${ }^{5}$ Algal Biotechnology Unit, Biological and Agricultural Research Division, National Research Centre, Dokki, Giza, Egypt (Affiliation ID: 60014618).
}

\begin{tabular}{|c|c|}
\hline ARTICLE INFO & ABSTRACT \\
\hline Article $\mathrm{h}$ & \multirow{12}{*}{$\begin{array}{l}\text { Diabetes mellitus is a chronic degenerative disease. In the developed countries, it is considered as the third leading } \\
\text { cause of death following heart and cancer diseases. The most effective algal extract was prepared from Nannochloropsis } \\
\text { oculata to treat diabetes-induced by Streptozotocin (STZ). In the present study, STZ showed a significant }(P<0.05) \\
\text { increase in glucose and C-reactive protein (CRP) levels associated with a decline in insulin level. This was parallel to } \\
\text { histopathological alterations in the pancreas of diabetic rats. The } N \text {. oculata algal extract lowered glucose and CRP } \\
\text { levels significant }(P<0.05) \text { with restoring the insulin level to normalcy. The electrophoretic protein and lipoprotein } \\
\text { patterns showed that STZ caused the disappearance of several normal bands. The } \alpha \text {-amylase and } \alpha \text {-esterase (EST) } \\
\text { were expressed severely and represented as one thick band in the diabetic group. Also, STZ caused qualitative } \\
\text { alterations in the arrangement of the bands of } \beta \text {-EST pattern. The algal extract decreased the quantity of } \alpha \text {-amylase } \\
\text { and } \alpha \text {-EST bands and restored the normal } \beta \text {-EST bands. Furthermore, STZ decreased the number of the bands in the } \\
\text { electrophoretic catalase (CAT) and peroxidase (POX) patterns associated with the existence of abnormal bands. The } \\
\text { algal extract restored the normal bands with hiding the abnormal ones. STZ induced cleavage of the genomic DNA } \\
\text { leading to the existence of several unique bands. The algal extract maintained the integrity of the genomic DNA. The } \\
\text { study concluded that algal extract showed an ameliorative effect against diabetes induced by STZ at biochemical, } \\
\text { histopathological and molecular levels in the pancreas of rats. }\end{array}$} \\
\hline$/ 02 / 2018$ & \\
\hline$\pi$ & \\
\hline Available online: $29 / 06 / 2018$ & \\
\hline & \\
\hline Diabetes mellitus, & \\
\hline Nannochloropsis oculata, & \\
\hline Electrophoresis, Isoenzymes, & \\
\hline Genomic DNA. & \\
\hline & \\
\hline & \\
\hline & \\
\hline
\end{tabular}

\section{INTRODUCTION}

Diabetes mellitus is a chronic degenerative disease. It is considered as one of the most common endocrine disorders. It is a serious complex and a multifarious group of metabolic syndromes that disturbs the metabolism of carbohydrates, fats, and proteins (Kar et al., 1999). It is characterized by elevation of glucose level by mean of hyperglycemia which subsequently leads

${ }^{*}$ Corresponding Author

Wael Mahmoud Aboulthana, Biochemistry Department, Genetic

Engineering and Biotechnology Division, National Research Centre, 33 Bohouth St., Dokki, Giza,Egypt.E-mail:wmkamel83@ @otmail.com to hypercholesterolemia, hypertriglyceridemia and cardiovascular diseases. Moreover, it leads to renal failure, blindness or diabetic cataract worldwide (Prasad et al., 2009). It is caused as a result of underproduction of pancreatic insulin and/or lowered sensitivity of the tissue to insulin by mean of insulin resistance (Kumar et al., 2015). According to the worldwide survey reported by World Health Organization (WHO), it was found that diabetes affects about $10 \%$ of the population and more than 220 million people worldwide suffer from this disease (Kim et al., 2006). As documented by Guariguata et al. (2011), it was emphasized that diabetes is considered as a major cause of morbidity and mortality. Moreover, in the developed countries, it is arranged as the third 
leading cause of death following heart and cancer diseases.

Streptozotocin (STZ) is a naturally occurring nitrosourea product of Streptomyces achromogenes. It exerts a selectively direct necrotic effect on $\beta$ cells and insulin-producing pancreatic endocrine cells causing hyperglycemia within 48-72 $\mathrm{h}$ when it is injected intraperitoneally (Kumar et al., 2015). Although STZ is less toxic than alloxan during the experimental induction of diabetes mellitus, it induces various side effects represented by liver and kidney injury with depression of bone marrow (Brenna et al., 2003). Proteins are the most important organic constituents in tissues because of all the enzymes and hormones which regulate all biological activities are consisting of proteins. In addition, it is well known that proteins exhibit a pivotal role in the tissue through activating the compensatory mechanisms under toxic stress (Venkataramana Sandhya et al., 2006). For this reason, assessment of protein and enzymes activities can be considered as an effective tool for revealing the physiological status of tissues (Manoj, 1999). Diet, exercise, oral hypoglycemic drugs, and insulin therapy belong to the therapeutic strategy for diabetes treatment. Currently, there are several available drugs suitable to decrease hyperglycemia in diabetic patients (Mutalik et al., 2003). The beneficial effects of standard hypoglycemic drugs are well documented during the recent studies which postulated that activity of the standard medications is still not effective against the natural progression of the disease. Although insulin is considered as an effective hyperglycemic therapy, it exhibits shortcomings due to its ineffectiveness on oral administration and fatal hypoglycemia in the event of excess dosage (Kasiviswanath et al., 2005). Moreover, biguanides and sulphonylurea belong to the oral antidiabetic agents which are available with insulin for diabetes treatment but associated with adverse side effects (Patil et al., 2012). As a result of the undesirable side effects of these drugs, it is necessary to search in the nature for new drug/compound for overcoming problems of this disorder without side effects (Noor et al., 2008). For all these reasons, the WHO recommended that it is necessary to evaluate the effectiveness of the natural hypoglycemic agents of plants origin for conditions safe modern drugs in traditional medicine (WHO, 1980). This leads to increasing demand for the natural drugs which frequently exhibit higher affectivity and lowest toxicity than the synthetic ones (Loew and Kaszkin, 2002).

Marine organisms are rich sources of biologically active metabolites. So far, many of these primary and secondary metabolites have been isolated and being developed as new pharmaceutical products (Schwartsmann et al., 2001; Selvendran, 2013). It was emphasized recently that algae have attracted global attention due to its potential to produce lots of valuable natural products (Enwereuzoh and Onyeagoro, 2014). Nannochloropsis oculata is a small green microalga genus which belongs to the class Eustigmatophyceae. It is well known marine eukaryotic unicellular phytoplankton in aquaculture by its nutritional value and potency to produce highly valuable compounds (Scholz et al., 2014; Hamidi et al., 2014; Kent et al., 2015). The active components extracted from $N$. oculata exhibited the ability to reduce the generation of the free radicals associated with increasing capacity of the antioxidant system (Yanuhar et al., 2011; Selvendran, 2013). These algal components in N. oculata may aid in regulating glucose, lipids, and lipoproteins during the metabolic pathways in the endocrine tissues of diabetic rats. Also, they may contribute to the maintenance of the intestinal tissues (Nuno et al., 2013). Moreover, it was documented recently that the sterol content in $N$. oculata might provide a promising antiinflammatory and anti-cancer role (Sanjeewa et al., 2016). The purpose of this study was to appraise the potential use of the most effective microalgae $N$. oculata extract in the treatment of diabetes mellitus induced by STZ using a rat model.

\section{MATERIALS AND METHODS}

All other chemicals and reagents used were of analytical grade and of the highest purity. Acrylamide, Bis-acrylamide, Ammonium persulfate (APS), N,N,N,NTetramethylethylnediamine (TEMED), Coomassie Brilliant Blue G-250 (CBBR-250) and Sudan Black B (SBB) were procured from Sigma-Aldrich. Hematoxylin and Eosin stains were obtained from SRL, India and the chemicals used for in-gel esterase staining including $\alpha$ - and $\beta$-naphthyl acetate, Fast Blue RR was purchased from Qualigens Fine Chemicals, India. Streptozotocin (STZ) was purchased from Sisco Research Laboratories Pvt. Ltd., Mumbai, India. Benzidine and 2-Thio-barbituric Acid (TBA) were purchased from Sigma Chemicals Company (London, UK). The PCR kit and primers were purchased from Promega.

\section{Microalgae strain and preparation}

Nannochloropsis oculata alga(NNO-1 UTEX Culture LB 2164) was cultivated and collected from the Algal Biotechnology Unit, Biological and Agricultural Research Division, National Research Centre, Dokki, Giza, Egypt. Microalgae concentration and biochemical composition were controlled according to the method described by Nuno et al. (2013). The strain was cultivated under conditions consisting of the $\mathrm{f} / 2$ medium at $21^{\circ} \mathrm{C}, 30 \mathrm{ppm}$ $\mathrm{NaCl}, \mathrm{pH} 8.2$, and under $2 \times 75 \mathrm{~W}$ fluorescent lights. Samples were collected on the $6^{\text {th }}$ day and centrifuged at $3588 \mathrm{~g}$ and $20^{\circ} \mathrm{C}$. The precipitated microalgae were centrifuged again for $10 \mathrm{~min}$ at $897 \mathrm{~g}$ and $20^{\circ} \mathrm{C}$. Recovered biomass was freeze-dried and stored separately by species at $-20^{\circ} \mathrm{C}$ until use.

\section{Total polyphenols and antioxidant activity}

The concentration of the total polyphenols (Singleton and Rossi, 1965) and total reducing power (Oyaizu, 1986) were estimated in different algal extracts to select the most suitable extract. Percentage of the antioxidant activity was determined by 2,2-diphenyl-1-picrylhydrazyl-hydrate (DPPH) free radical assay (Brand-Williams et al., 1995). Moreover, the cytotoxic activity was determined based on the method suggested by Mosmann (1983) on human hepatocellular carcinoma cell line (HepG2) purchased from CSIR-National Chemical Laboratory, Pune, India.

\section{Administration of the $N$. oculata algal extract}

The crude algal material of the most effective extract was dried by incubation at $50^{\circ} \mathrm{C}$ for $72 \mathrm{~h}$ and then crushed into powder in an electric blender. Fifty-six adult albino mice of weight 20-25 $\mathrm{g}$ were used to evaluate the median lethal dose $\left(\mathrm{LD}_{50}\right)$ and hence the therapeutic dose of the algal extract. It was divided into 7 groups each of 8 mice. The groups were treated orally with rising doses of 500, 1000, 2000, 3000, 4000, 5000 and $6000 \mathrm{mg} / \mathrm{kg}$ body weight (b.w.) of algal extract. Mortality was recorded after $24 \mathrm{hrs}$ of the extract treatment. The $\mathrm{LD}_{50}$ was calculated using equation 
suggested by Paget and Barnes (1964). The therapeutic dose of the algal extract was administrated orally by stomach tube at 250 $\mathrm{mg} / \mathrm{Kg} /$ day.

\section{Animals and treatments}

Healthy sixty adult male Wistar rats (weighing 170-200 g) were housed in ten per cage. The animals were provided with water ad libitum and standard food and maintained under normal environmental conditions at $25 \pm 2{ }^{\circ} \mathrm{C}$.

\section{Ethics statement}

The experimental design and animal handling were carried out based on the experimental protocol approved by Institutional Animal Ethics Committee of National Research Centre, Dokki, Giza, Egypt (No: 471/2016) and were conducted in accordance with guidelines as per "Guide for the care and use of laboratory animal" and with permission from Committee for the Purpose of Control and Supervision of Experiments on Animals.

\section{Induction of diabetes mellitus}

A fresh STZ solution was prepared at a dose of $60 \mathrm{mg} /$ kg b.w. by dissolving STZ in $100 \mathrm{mM}$ citrate buffer (pH 4.5) and injected intraperitoneally (i.p.) in a volume of $1 \mathrm{ml} / \mathrm{kg} \mathrm{b.w}$. to rats after fasting overnight (Archana et al., 2001). STZ injected animals exhibited massive glycosuria and hyperglycemia within few days. Diabetes was confirmed in STZ injected rats by measuring the fasting blood glucose concentration. Rats were considered as diabetic when a blood glucose level reaches $200 \mathrm{mg} / \mathrm{dl}$.

\section{Experimental design}

The rats were randomly divided into six groups. Group I (termed as a control group): Rats were received distilled water for 21 days and fed with a normal diet as ad libitum. Group II (termed as N. oculata algal extract treated group): Rats were treated with aqueous algal extract at a dose of $250 \mathrm{mg} / \mathrm{Kg}$ for 21 days and fed with normal diet. Group III (termed as diabetic rats treated with commercial insulin): Rats were injected i.p. with STZ at a dose of $60 \mathrm{mg} / \mathrm{kg}$ b.w. and then treated with insulin (Insulatard human insulin purchased from Novo Nordisk A/S, DK-2880 Bagsvaerd, Denmark) at a dose of 4 to $8 \mathrm{U}$ followed by 1 to $2 \mathrm{U}$ daily to obtain euglycemia for 7 days. Group IV (termed as a diabetic group): Rats were injected with a single dose of STZ i.p. and then diabetic rats were sacrificed after one week of STZ injection. Group V (termed as a Simultaneously treated group): Rats injected with STZ i.p. and administrated algal extract in a parallel manner for 21 days. Group VI (termed as a post-treated group): Rats injected with STZ i.p. for 7 days then treated with algal extract for 21 days.

\section{Collection of samples}

At end of the experiment (i.e., on $21^{\text {st }}$ day), the animals were anesthetized through slight exposure to diethyl ether. The blood samples were drawn from retro-orbital plexus and divided into two parts, part one: deposited in $\mathrm{NaF}$ glucose vacuum tubes (Becton Dickinson, New York, NJ) for plasma separation during glucose estimation. Part two of the blood samples: was allowed for clotting at room temperature and then centrifuged at $3000 \mathrm{rpm}$ for 15 minutes; the serum was separated and kept in clean stoppered vials at $-20^{\circ} \mathrm{C}$ until the biochemical assay. After sacrificing the animals by cervical dislocation, the pancreas tissues were excised and washed in ice-cold saline then homogenized in $0.01 \mathrm{M}$ Tris buffer ( $\mathrm{pH}$ 7.4). Aliquots of this homogenate were used for measuring lipid peroxidation product (LPO) and for the different electrophoretic assays.

\section{Biochemical analysis}

Glucose, Serum Alanine Aminotransferase (ALT), Aspartate Aminotransferase (AST), Alkaline Phosphatase (ALP), Urea, Creatinine, Total Protein, Cholesterol, Triglycerides, HDL-cholesterol, LDL-cholesterol, Creatine Phosphate Kinase (CPK) and Lactate Dehydrogenase (LDH) were measured in all experimental animals by using commercially available kits purchased from Spectrum Diagnostics Egyptian Company for Biotechnology (Cairo, Egypt). Level of plasma insulin was determined with sandwich enzyme-linked immunosorbent assay kit (ELISA, Boehringer Mannheim, Mannheim, Germany). Serum C-reactive protein (CRP) level was assayed using a solid phase ELISA that uses affinity purified anti-rat CRP antibodies for solid phase (microtiter wells) immobilization and horseradish peroxidize (HRP) conjugated anti-rat CRP antibodies for detection. The LPO product was determined in the pancreatic tissue homogenates by spectrophotometrical technique at wavelength $535 \mathrm{~nm}$ using a UV-vise spectrophotometer (Shimadzu UV-2401 pc) based on the method suggested by Ohkawa et al. (1979).

\section{Statistical analysis}

The analyses were expressed as mean \pm standard error (SE) in the tables and figures. Statistical comparisons were carried out by one-way analysis of variance (one-way ANOVA) followed by least significant difference (LSD) test and confirmed by Bonferroni test. A " $P$ " value of less than 0.05 indicates the statistically significant difference.

\section{Histopathological examination}

After sacrifice, small portions were autopsied from the splenic lobes of the pancreas were taken from different groups and immediately preserved in $10 \%$ neutral buffered formalin solution for $24 \mathrm{hr}$. The tissue specimens were dehydrated in serial dilutions of alcohol solutions, cleared in xylene and embedded in paraffin then sectioned at $4 \mu \mathrm{m}$. Subsequently, the tissue sections were collected on glass slides and deparaffinized then stained by hematoxylin and eosin (H\&E) stain for histological examination according to the method described by Banchroft et al. (1996). The histopathological changes were scored as mean of at least five rats and assigned between 0 (no damage) and +++ (maximal damage) for each investigated section according to the method suggested by Dommels et al. (2007).

\section{Electrophoretic patterns}

The tissues were washed and ground then homogenized in water-soluble extraction buffer. The homogenates were centrifuged at $10,000 \mathrm{rpm}$ for $15 \mathrm{~min}$ at $4^{\circ} \mathrm{C}$. The supernatants containing water-soluble proteins were transferred to new tubes. Samples of each group were pooled together and used as one sample. Total protein concentration was determined in all pooled samples using bovine serum albumin as standard according to 
Bradford (1976). Quantities of protein should be equal in all wells and must be about $70 \mu \mathrm{g}$ protein.

The native proteins were separated through Polyacrylamide Gel Electrophoresis (PAGE) according to the methods described by Hames, (1990) and modified by Darwesh et al. (2015) who documented that samples, gels, and running buffers were lacking sodium dodecyl sulfate. The native bands were stained by Coomassie Brilliant Blue G-250 for visualizing protein bands. Furthermore, the native gel was stained for lipids with Sudan Black B (SBB) by mean of isoelectrophoresis (Subramaniam and Chaubal, 1990).

\section{Electrophoretic localization of in-gel enzyme activity}

The native gel was stained for electrophoretic catalase (CAT) and peroxidase (POX) patterns according to the method suggested by Siciliano and Shaw (1976) and Rescigno et al. (1997), respectively. It was processed for localization of in-gel $\alpha$-amylase activity by the method suggested by Rammesmayer and Praznik (1992) by incubation with a solution containing soluble starch followed by staining with iodine solution. Moreover, the native gel was incubated in reaction mixture containing $\alpha, \beta$-naphthyl acetate $\left(5.58 \times 10^{-3} \mathrm{mM}, \mathrm{pH} 7.5\right)$ as substrates along with dye coupler Fast Blue RR based on the method suggested by Baker and Manwell (1977) and modified recently by Ahmad et al. (2012) for studying localization of in-gel $\alpha$ - and $\beta$-esterase (EST) activities.

Table 1: Polyphenol concentration, Iron reducing power, antioxidant and anticancer activities in different $N$. oculata algal extracts.

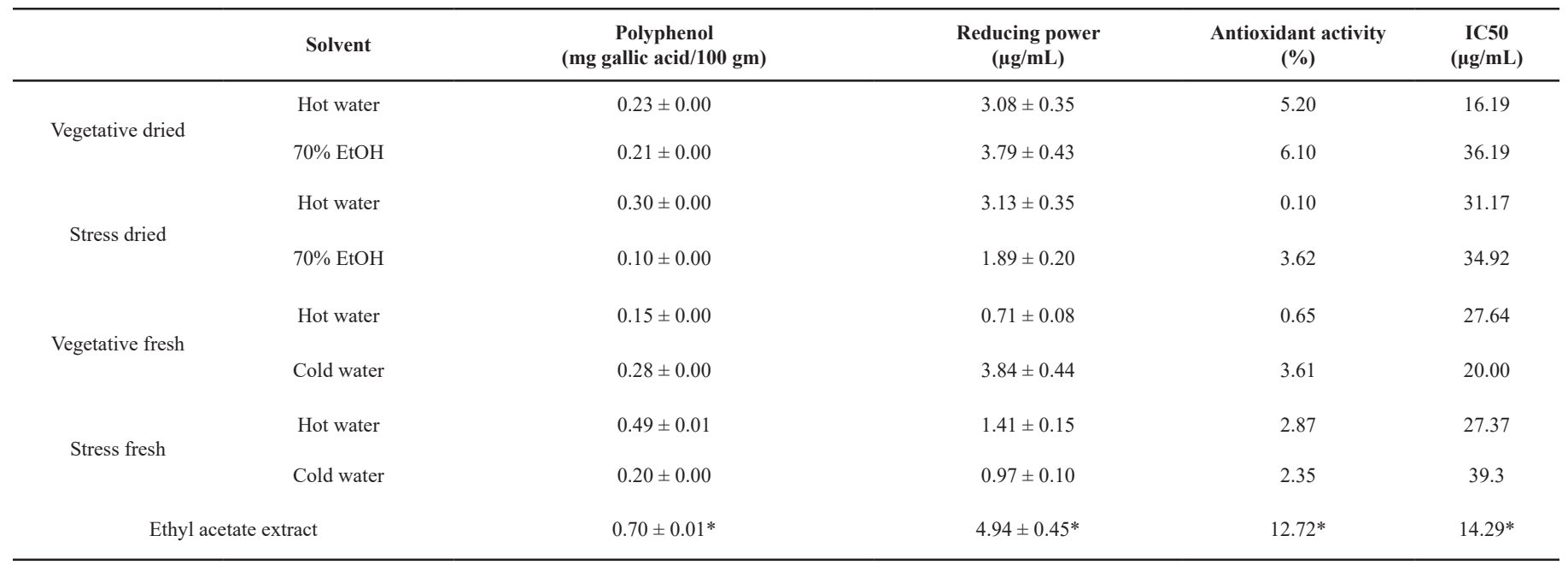

*: The most effective extract with the highest polyphenol concentration, reducing power, antioxidant and anticancer activity.

\section{Genomic DNA pattern}

The genomic DNA was extracted from pancreatic tissues using the method described by Barker et al. (2004). It was amplified with 5 random primers of different nucleotide sequences (OPA04 (5'-AATCGGGCTG-3'), OPA-05 (5'-AGGGGTCTTG-3'), OPA-07 (5'-GAAACGGGTG-3'), OPA-10 (5'-GTGATCGCAG-3') and OPA-11 (5'-CAATCGCCGT-3')) during the polymerase chain reaction (PCR) based on method suggested by Rapley (1998). The amplification process was performed using thermal cycler (Progeny 30, Techno, Cambridge Ltd. Dux ford Cambridge, UK) through the thermal program initial denaturation at $94^{\circ} \mathrm{C}$ for $5 \mathrm{~min}$. followed by 40 cycles of DNA amplification. Each cycle was consisting of denaturation at $94^{\circ} \mathrm{C}$ for $2 \mathrm{~min}$. then annealing at $40^{\circ} \mathrm{C}$ for $2 \mathrm{~min}$. and extension at $72^{\circ} \mathrm{C}$ for $7 \mathrm{~min}$. After separation of the amplified fragments on $2 \%$ agarose gel, they visualized on a UV transilluminator then photographed by Gel Documentation System.

\section{Data analysis}

The polyacrylamide and agarose gel plates were photographed and analyzed using Quantity One software (Version 4.6.2). The relative mobility (Rf), band percent (B \%) and band quantity (Qty) of the electrophoretically separated bands were determined. Furthermore, percent of the similarity index (SI \%) was calculated to compare all treated groups to control group according to equation suggested by Nei and Li (1979).

\section{RESULTS}

As illustrated in Table 1, it was found that the most effective algal extract noticed with high concentrations of the total polyphenols, total reducing power and free radical scavenging activity $0.70 \pm 0.01 \mathrm{mg}$ gallic acid/100 gm, $4.94 \pm 0.45 \mu \mathrm{g} / \mathrm{ml}$ and $12.72 \%$, respectively. Furthermore, the lowest cell viability $\%$ of cancer cells was noticed with this effective extract which exhibited $\mathrm{IC}_{50} 14.29 \mu \mathrm{g} / \mathrm{mL}$.

\section{Biochemical measurements}

As reported in Table 2, it was noticed that STZ caused significant $(P<0.05)$ elevation in circulating glucose and CRP level and significant $(P<0.05)$ decrease in insulin level with respect to control. With respect to STZ induced diabetic group, the $N$. oculata algal extract decreased glucose and CRP levels in parallel to an elevation of insulin level significantly $(P<0.05)$. As compared to control, STZ caused significant $(P<0.05)$ elevation in ALT, AST and ALP levels. The $N$. oculata algal extract decreased activities of these enzymes significantly $(P<0.05)$.

As shown in Table 3, significant $(P<0.05)$ elevation was observed in urea and creatinine levels associated with significant 
$(P<0.05)$ decrease in TP level of STZ induced diabetic rats. The $N$. oculata algal extract lowered levels of these parameters significantly $(P<0.05)$ with restoring TP level to a normal value when compared to STZ induced diabetic group.

Table 2: Effect of STZ-induced diabetes and daily oral administration of $N$. oculata algal extract on levels of glucose, insulin, C-reactive protein (CRP) and liver enzymes.

\begin{tabular}{|c|c|c|c|c|c|c|}
\hline & GI & GII & GIII & GIV & GV & GVI \\
\hline Glucose (mg. $\left.\mathrm{dl}^{-1}\right)$ & $114.7 \pm 1.08$ & $117.90 \pm 0.81$ & $118.00 \pm 0.87$ & $407.67^{\mathrm{a}} \pm 4.13$ & $227.50^{\mathrm{ab}} \pm 1.40$ & $126.40^{\mathrm{ab}} \pm 1.08$ \\
\hline Insulin $(\mu \mathrm{g} / \mathrm{L})$ & $10.50 \pm 0.03$ & $10.41 \pm 0.03$ & $10.40 \pm 0.04$ & $4.51^{\mathrm{a}} \pm 0.04$ & $7.84^{\mathrm{ab}} \pm 0.06$ & $8.84^{\mathrm{ab}} \pm 0.02$ \\
\hline CRP (ng. ml $l^{-1}$ ) & $2.73 \pm 0.03$ & $2.75 \pm 0.03$ & $2.84 \pm 0.02$ & $12.47^{\mathrm{a}} \pm 0.03$ & $3.54^{\mathrm{ab}} \pm 0.04$ & $2.90^{\mathrm{ab}} \pm 0.05$ \\
\hline $\operatorname{ALT}\left(\mathrm{U}^{-L^{-1}}\right)$ & $30.10 \pm 0.43$ & $31.00 \pm 0.37$ & $31.00 \pm 0.24$ & $90.17^{\mathrm{a}} \pm 1.08$ & $43.10^{\mathrm{ab}} \pm 0.53$ & $33.60^{\mathrm{ab}} \pm 0.50$ \\
\hline AST (U.L-1) & $29.10 \pm 0.62$ & $30.30 \pm 0.40$ & $30.44 \pm 0.53$ & $170.17^{\mathrm{a}} \pm 0.79$ & $42.60^{\mathrm{ab}} \pm 0.40$ & $34.80^{\mathrm{ab}} \pm 0.25$ \\
\hline ALP (U.L $\left.{ }^{-1}\right)$ & $77.70 \pm 0.58$ & $77.40 \pm 0.45$ & $79.33 \pm 0.33$ & $234.00^{\mathrm{a}} \pm 1.51$ & $126.40^{\mathrm{ab}} \pm 0.87$ & $84.00^{\mathrm{ab}} \pm 0.58$ \\
\hline
\end{tabular}

a: Values compared to control group (GI); b: Values compared to STZ induced diabetic group (GIV) (significant $P<0.05$ ).

Group I: Control group, Group II: N. oculata algal extract treated group, Group III: diabetic rats treated with commercial insulin, Group IV: diabetic group, Group V: Simultaneously treated group, Group VI: Post-treated group.

Table 3: Effect of STZ-induced diabetes and daily oral administration of $N$. oculata algal extract on kidney functions.

\begin{tabular}{lcccccc}
\hline & GI & GII & GIII & GIV & GV & GVI \\
\hline Urea $\left(m g . d l^{-1}\right)$ & $42.40 \pm 0.45$ & $41.70 \pm 0.37$ & $42.33 \pm 0.33$ & $74.50^{\mathrm{a}} \pm 0.72$ & $57.60^{\mathrm{ab}^{\mathrm{a}} \pm 0.31}$ & $46.10^{\mathrm{ab}} \pm 0.48$ \\
Creat. $\left(\mathrm{mg.dl^{-1 }}\right)$ & $0.73 \pm 0.00$ & $0.74 \pm 0.01$ & $0.74 \pm 0.00$ & $0.94^{\mathrm{a}} \pm 0.01$ & $0.73^{\mathrm{b}} \pm 0.00$ & $0.73^{\mathrm{b}} \pm 0.01$ \\
TP $\left(\right.$ g.dl $\left.^{-1}\right)$ & $6.19 \pm 0.01$ & $6.20 \pm 0.01$ & $6.16 \pm 0.03$ & $4.24^{\mathrm{a}} \pm 0.03$ & $5.28^{\mathrm{ab}} \pm 0.01$ & $6.28^{\mathrm{ab}} \pm 0.02$ \\
\hline
\end{tabular}

a: Values compared to control group (GI) ; b: Values compared to STZ induced diabetic group (GIV) (significant $P<0.05$ ).

Group I: Control group, Group II: N. oculata algal extract treated group, Group III: diabetic rats treated with commercial insulin, Group IV: diabetic group, Group V: Simultaneously treated group, Group VI: Post-treated group.

Table 4: Effect of STZ-induced diabetes and daily oral administration of N. oculata algal extract on lipid profile and heart enzymes.

\begin{tabular}{|c|c|c|c|c|c|c|}
\hline & GI & GII & GIII & GIV & GV & GVI \\
\hline Cholest. (mg. $\mathrm{dl}^{-1}$ ) & $83.30 \pm 0.42$ & $84.00 \pm 0.47$ & $85.78 \pm 0.60$ & $134.83^{\mathrm{a}} \pm 0.83$ & $104.50^{\mathrm{ab}} \pm 2.21$ & $89.30^{\mathrm{ab}} \pm 0.67$ \\
\hline T.Gs (mg.dl-1) & $101.80 \pm 1.53$ & $101.70 \pm 1.78$ & $101.89 \pm 2.04$ & $371.33^{\mathrm{a}} \pm 2.26$ & $217.70^{\mathrm{ab}} \pm 0.72$ & $119.60^{\mathrm{ab}} \pm 1.45$ \\
\hline LDL-c (mg.dl $\left.{ }^{-1}\right)$ & $29.47 \pm 0.28$ & $29.77 \pm 0.43$ & $30.42 \pm 0.47$ & $61.08^{\mathrm{a}} \pm 0.36$ & $36.04^{\mathrm{a}} \pm 0.15$ & $30.17^{\mathrm{b}} \pm 0.13$ \\
\hline HDL-c $\left(\mathrm{mg} \cdot \mathrm{dl}^{-1}\right)$ & $34.90 \pm 0.50$ & $34.20 \pm 0.53$ & $33.56 \pm 0.29$ & $16.30^{\mathrm{a}} \pm 0.10$ & $33.00^{\mathrm{b}} \pm 0.45$ & $34.50^{\mathrm{b}} \pm 0.52$ \\
\hline CPK (U.L $\left.{ }^{-1}\right)$ & $62.81 \pm 0.36$ & $62.91 \pm 0.28$ & $62.60 \pm 0.38$ & $227.17^{\mathrm{a}} \pm 2.27$ & $125.40^{\mathrm{ab}} \pm 1.27$ & $63.24^{b} \pm 0.33$ \\
\hline LDH (U.L $\left.{ }^{-1}\right)$ & $86.10 \pm 0.50$ & $88.10 \pm 0.50$ & $88.22 \pm 0.68$ & $227.33^{\mathrm{a}} \pm 2.32$ & $128.30^{\mathrm{ab}} \pm 0.82$ & $94.50^{\mathrm{ab}} \pm 0.45$ \\
\hline
\end{tabular}

a: Values compared to control group (GI); b: Values compared to STZ induced diabetic group (GIV) (significant $P<0.05$ ).

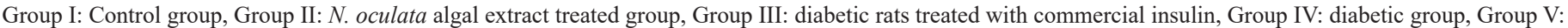
Simultaneously treated group, Group VI: Post-treated group.

As revealed in Table 4, levels of total cholest., T.Gs, and LDL-c elevated significantly $(P<0.05)$ associated with significant $(P<0.05)$ decline in HDL-c in STZ induced diabetic group with respect to control. The treatment with $N$. oculata algal extract lowered levels of the elevated measurements with increasing the in HDL-c level significantly $(P<0.05)$ as compared to STZ induced diabetic group. Moreover, it was noticed that STZ caused significant $(P<0.05)$ increase in CPK and LDH levels as compared to control. The $N$. oculata algal extract decreased activities of these enzymes significantly $(P<0.05)$ with respect to STZ induced diabetic group.
While, as illustrated in Figure 1, STZ caused significant $(P<0.05)$ elevation in LPO level in pancreas tissue as compared to control. The $N$. oculata algal extract lowered the LPO level significantly ( $P$ $<0.05$ ) when compared to STZ induced diabetic group.

\section{Histopathological examination}

As illustrated in Figure 2a, it was revealed that there was no histopathological alteration in the pancreas of control rats. Normal histological structure of the islands of Langerhans cells (S) as the endocrine portion as well as the acini (a) with the duct 
system as exocrine one was noticed. In $N$. oculata algal extract treated group, there was no histopathological alteration and no deviation from the control group (Figure $2 b$ ). While in group III there was the normal histological structure of islands of the Langerhans cells (S) associated with mild dilatation in the duct system (pd) (Figure 2c). In contrast, in group IV (diabetic group), atrophy was detected in the islands of Langerhans cells $(\mathrm{S})$ in a diffuse manner (high degree of severity $+++; 75-100 \%$ ) associated with congestion in the stromal blood vessels (V) (Figure 2d). Atrophy was only detected in the islands of Langerhans cells (S) in a diffuse manner (mild degree of severity $+; 25-50 \%$ ) in group V (simult-treated group) (Figure 2e). While, in group VI (posttreated group), no histopathological alterations were detected in the islands of Langerhans cells (S) (Figure 2f).

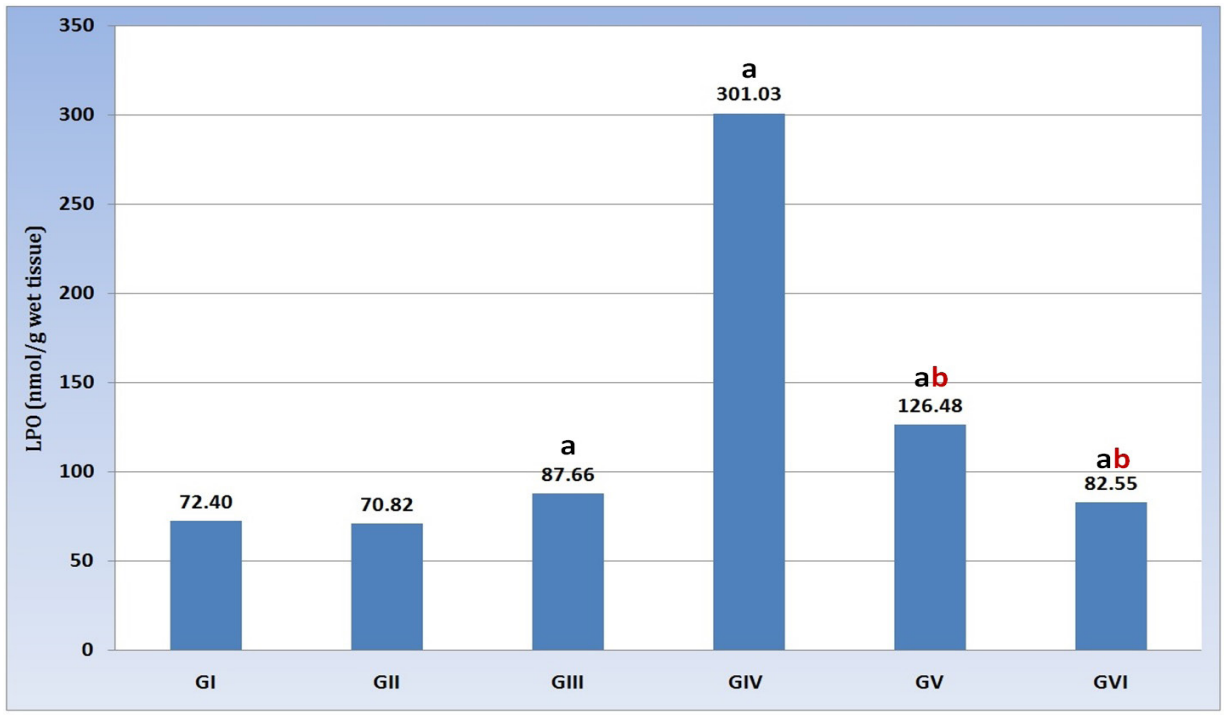

Fig. 1: Effect of STZ-induced diabetes and daily oral administration of $N$. oculata algal extract on LPO product in pancreas tissue. Group I: Control group, Group II: $N$. oculata algal extract treated group, Group III: diabetic rats treated with commercial insulin, Group IV: diabetic group, Group V: Simultaneously treated group, Group VI: Post-treated group.
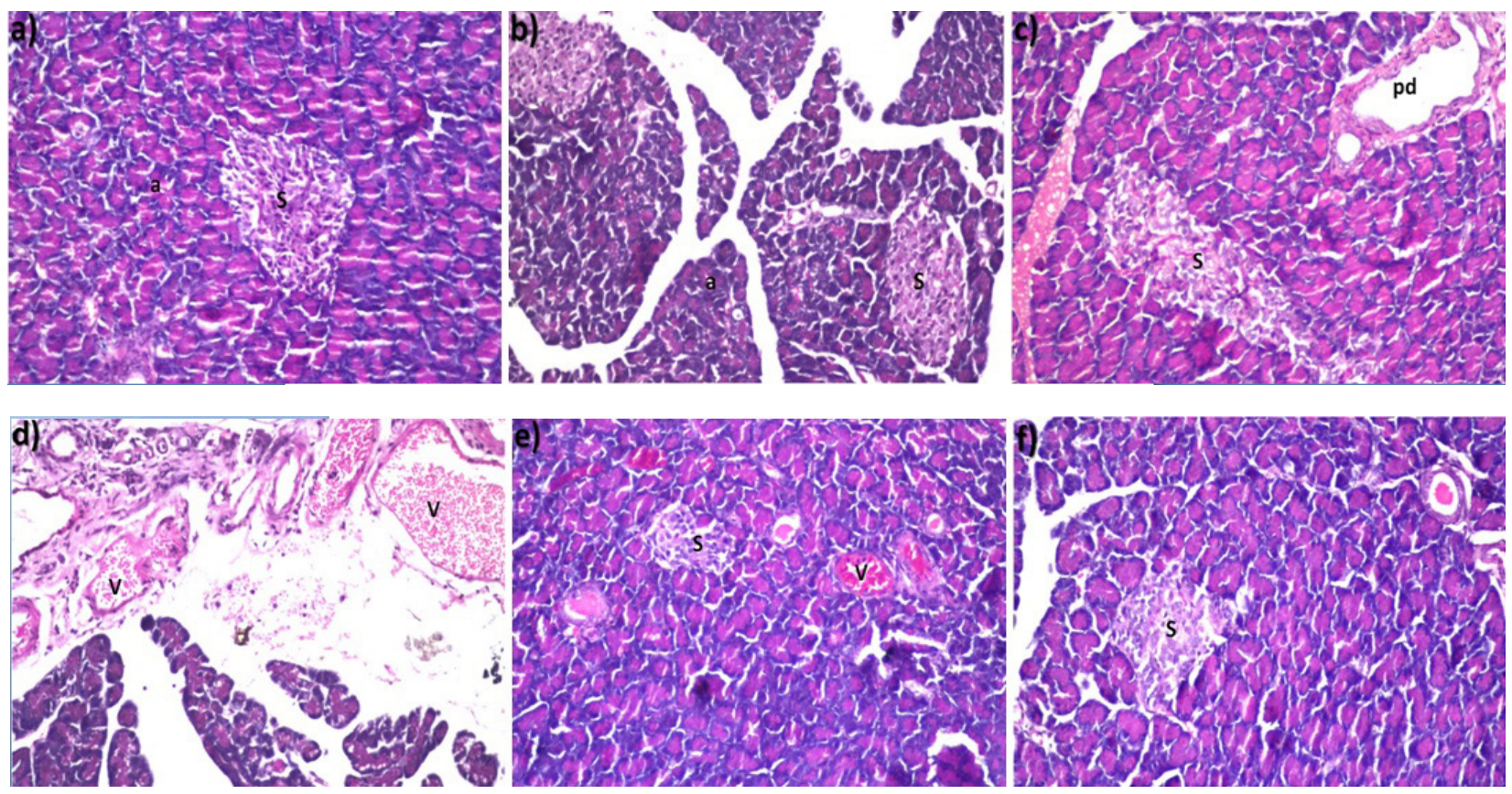

Fig. 2: Pancreas tissue showing a) control group (GI) with normal histological structure (H\&E, X 40), b) N. oculata algal extract treated group (GII) without deviation from control group (H\&E, X 40), c) STZ induced diabetes treated by commercial insulin (GIII) with normal histological structure and mild dilatation in the duct system (pd) (H\&E, X 40), d) STZ induced diabetes (GIV) with severe histological alterations (H\&E, X 40), e) simult-treated group (GV) with atrophy was only in islands of Langerhans cells (S) (H\&E, X 40) and f) post-treated group (GVI) without alterations and deviation from control group (H\&E, X 40).

\section{Electrophoretic patterns}

As compared to the corresponding control (Figure 3a), several protein bands disappeared in STZ induced diabetes with the appearance of one characteristic band (Rf 0.46, Int 2565.71 and 
Qty 10.86). Moreover, the lowest SI value was noticed with the STZ induced diabetic group (22\%). Also, it could be observed that STZ decreased bands number in the lipoprotein pattern without the existence of further bands (Figure $3 b$ ). The lowest SI value was observed with the STZ induced diabetic group (61.54\%) and this was constant with results of the protein pattern. The treatment with $N$. oculata algal extract restored all the normal bands and hence the SI values reached the highest value in the STZ induced diabetic group treated with $N$. oculata algal extract.

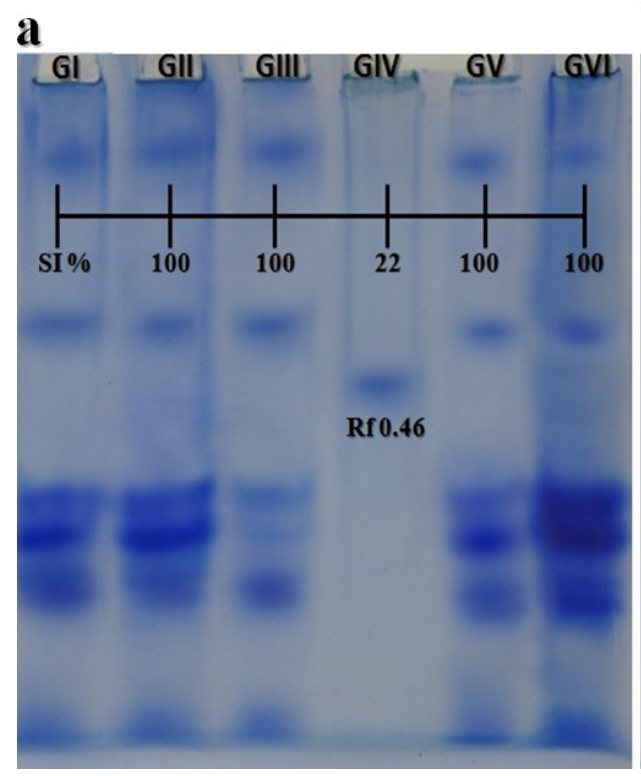

b

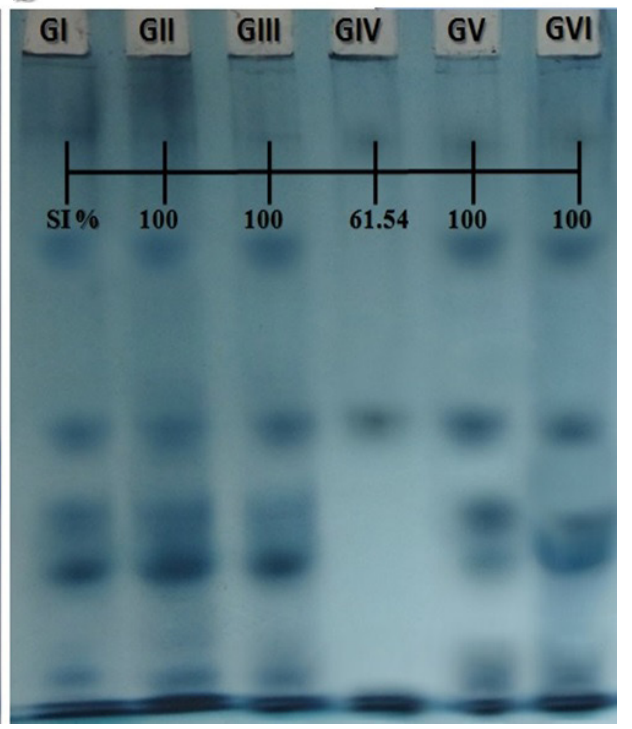

Fig. 3: Electrophoretic patterns showing the curative effect of $N$. oculata algal extract against streptozotocin-induced diabetes on a) native protein and b) lipoprotein in pancreas tissue of rats. Group I: Control group, Group II: $N$. oculata algal extract treated group, Group III: diabetic rats treated with commercial insulin, Group IV: diabetic group, Group V: Simultaneously treated group, Group VI: Post-treated group.

\section{Electrophoretic localization of in-gel enzyme activity}

As illustrated in Figure $4 \mathrm{a}, \alpha$-amylase was represented by only one thick band in STZ induced diabetic group ( Rf 0.06 , Int 426.3 and Qty 2.86). Also, in the STZ induced diabetic group treated with $N$. oculata algal extract, the enzyme was represented by the only band but with lower intensity and quantity (Rf 0.05 , Int 186.97 and Qty 1.21) with respect to the STZ induced diabetic group. In addition, $\alpha$-EST (Figure $4 \mathrm{~b}$ ) was represented by one thick band in STZ induced diabetic group (Rf 0.06, Int 399.24 and Qty 1.93). Furthermore, the treatment with $N$. oculata algal extract decreased the band intensity and quantity (Rf 0.04, Int 208.64 and Qty 0.94). On the other hand, STZ injection caused alterations in the $\beta$-EST pattern (Figure $4 \mathrm{c}$ ) represented by shifting the first band (EST-1) to be noticed with different data (Rf 0.04, Int 1873.50 and Qty 9.87) as compared to control. Moreover, the lowest SI value was noticed with the diabetic group $(50 \%)$. In the diabetic group treated with $N$. oculata algal extract, one abnormal band was noticed (Rf 0.04, Int 1026.33 and Qty 5.31) in addition to the normal bands. Moreover, the SI value in this group (SI 80) was higher than that in the diabetic group.

With respect to the corresponding control (Figure 5a), several CAT bands disappeared in STZ induced diabetes with the appearance of 2 bands (Rf 0.03, Int 545.65 and Qty 1.50; Rf 0.05, Int 1344.69 and Qty 3.69, respectively). Moreover, only one abnormal band was identified (Rf 0.02, Int 1107.42 and Qty 2.90) in STZ induced diabetic group treated with $N$. oculata algal extract. The SI value in STZ induced diabetic group $(28.57 \%)$ was lower than that in STZ induced diabetic group treated with N. oculata algal extract. Also, it could be observed that STZ decreased bands number in the POX pattern (Fig. 5b) with the existence of 2 abnormal bands (Rf 0.02, Int 1147.69 and Qty 3.54; Rf 0.63, Int 1430.87 and Qty 4.42, respectively). Furthermore, only one abnormal band was identified (Rf 0.01, Int 1308.45 and Qty 3.90) in STZ induced diabetic group treated with $N$. oculata algal extract. The lowest SI value was observed with the STZ induced diabetic group (28.57\%) and this was constant with results of the CAT pattern.

\section{Genomic DNA fragmentation}

As shown in Figure 6a, STZ induced cleavage of DNA into 4 oligonucleosome length fragments $(\mathrm{Rf} 0.16,0.51,0.76$ and 0.92; B \% 15.38, 26.24, 25.37 and 33.01; Qty 8.42, 14.36, 13.89 and 18.07, respectively). Based on result of the DNA fragmentation, the amplicon with the primer OPA-04 (Figure 6b) showed that STZ caused qualitative alterations appeared through disappearance of all normal bands with existence of 3 characteristic ones ( $\operatorname{Rf} 0.17,0.35$ and $0.48 ; \mathrm{B} \% 38.01,35.62$ and 26.37; Qty 0.91, 0.85 and 0.63, respectively). As revealed in Figure $6 \mathrm{c}$, the amplicon with the primer OPA-07 showed that STZ caused the disappearance of one normal band with the existence of 3 characteristic bands ( $R f 0.10,0.20$ and 0.31 ; B\% 14.66, 26.87 and $26.87 ; 1.09,1.99$ and 1.99 , respectively). As illustrated in Figs. 6d \&e, the amplicon showed that STZ exhibited the same mutagenic effect with the primers OPA-10 and OPA-11. These disturbances were represented qualitatively by disappearance of one normal band with existence of 2 characteristic ones at $\mathrm{Rf} 0.21$ and 0.36 (B\% 29.28 and 30.56; Qty 11.95 and 12.47, respectively) with OPA-10 and at Rf 0.23 and 0.39 (B \% 16.01 and 25.98 ; Qty 
0.34 and 0.55 , respectively) with the primer OPA-11. Moreover, STZ caused alterations with the primer OPA-12 (Figure 6f) represented by disappearance of all normal bands with existence of 5 characteristic ones $(\operatorname{Rf} 0.18,0.36,0.49,0.54$ and $0.78 ; \mathrm{B} \%$ $10.60,32.89,12.89,17.22$ and 26.71; Qty $0.35,1.10,0.42,0.57$ and 0.89 , respectively). The lowest SI Value was noticed with all the primers in STZ induced diabetic rats. The genomic DNA pattern remains integrated into the STZ induced diabetic group treated with $N$. oculata algal extract. The SI value reached the highest value in all $N$. oculata algal extract treated group.
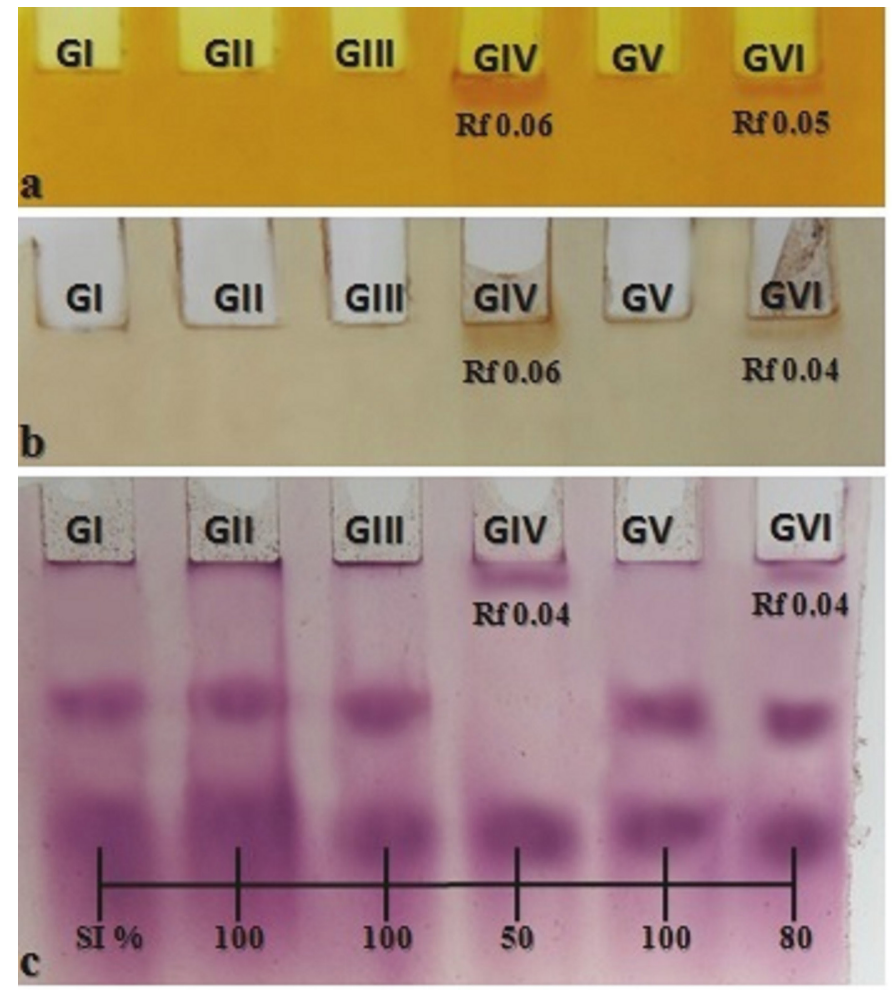

Fig. 4: Electrophoretic isozymes showing the curative effect of $N$. oculata algal extract against streptozotocin-induced diabetes on a) $\alpha$-amylase, b) $\alpha$-EST and c) $\beta$-EST in pancreas tissue of rats. Group I: Control group, Group II: $N$. oculata algal extract treated group, Group III: diabetic rats treated with commercial insulin, Group IV: diabetic group, Group V: Simultaneously treated group, Group VI: Post-treated group.

a

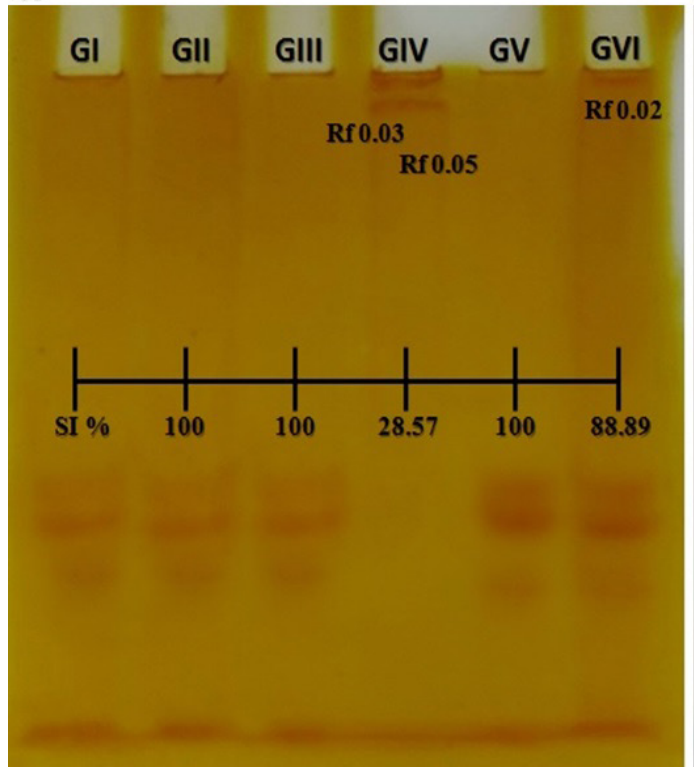

b

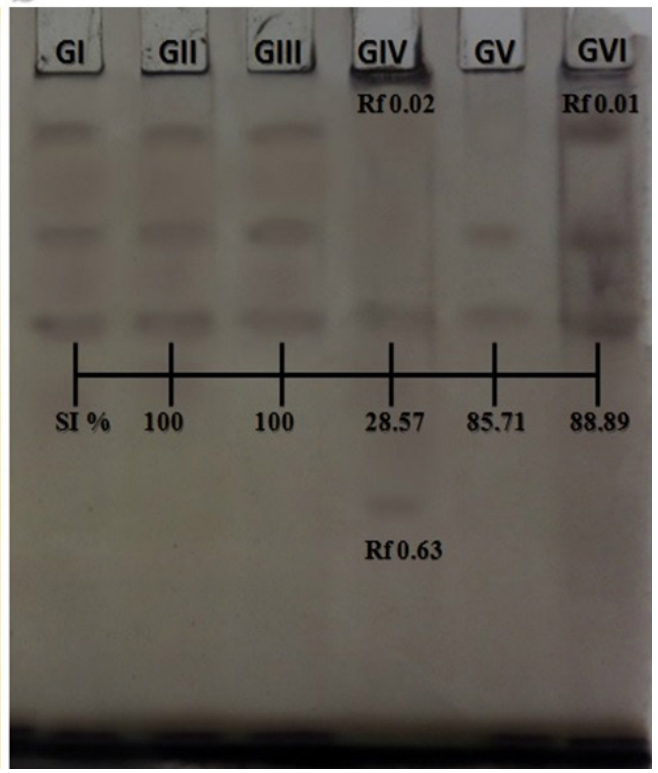

Fig. 5: Electrophoretic isozymes showing the curative effect of $N$. oculata algal extract against streptozotocin-induced diabetes on a) CAT pattern and b) POX pattern in pancreas tissue of rats. Group I: Control group, Group II: $N$. oculata algal extract treated group, Group III: diabetic rats treated with commercial insulin, Group IV: diabetic group, Group V: Simultaneously treated group, Group VI: Post-treated group. 

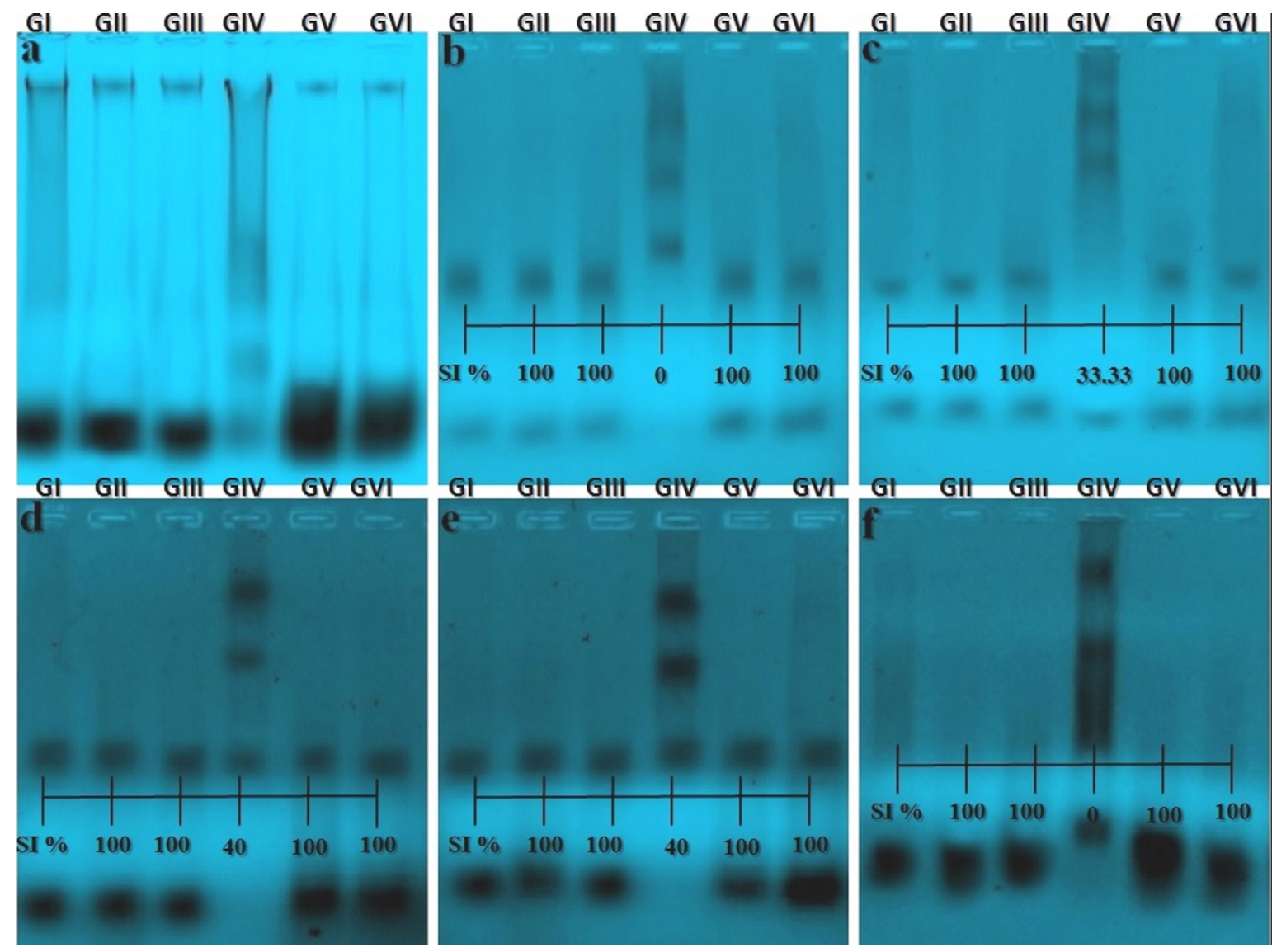

Fig. 6: Genomic DNA pattern showing the curative effect of $N$. oculata algal extract against streptozotocin-induced diabetes in pancreas tissue of rats a) DNA fragmentation, b) amplicon with random primer OPA-04, c) with primer OPA-07, d) with primer OPA-10, e) with primer OPA-11 and f) with the primer OPA-12. Group I: Control group, Group II: N. oculata algal extract treated group, Group III: diabetic rats treated with commercial insulin, Group IV: diabetic group, Group V: Simultaneously treated group, Group VI: Post-treated group.

\section{DISCUSSION}

The STZ is a broad-spectrum antibiotic. It induced diabetes through the destruction of $\beta$-cells of islets of Langerhans cells and insulin-producing pancreatic endocrine cells selectively. Subsequently, the blood glucose level elevated as a result of an insufficient release of insulin (Bailey and Flatt, 1986). The major disadvantage of STZ was represented by liver and kidney injury (Brenna et al., 2003). Because of the undesired sideeffects of synthetic antidiabetic drugs, it was necessary to search in the nature to suggest easily accessible natural products with hypoglycemic activity through insulinogenic effect (insulinreleasing stimulatory effect) by activation of the $\beta$ cells (Mahfouz, 2011). In the present study, STZ induced hyperglycemia. This was in accordance with Najafian et al. (2010). This might be attributed to destruction of the pancreatic $\beta$ cells and hence lowering level of insulin (Mythili et al., 2004). The CRP is the most effective and stable inflammatory marker (Ridker, 2003). Its level elevated in the circulation as a result of insulin deficiency (Jain et al., 2007). It has been attributed that the hypoglycemic effect of $N$. oculata algal extract may refer to its ability to restore integrity and function of pancreatic cells. This leads to elevation of insulin output associated with inhibition of the intestinal absorption of glucose (Elder, 2004). Hyperglycemia is related to various defects in metabolic pathways. It is associated with the generation of the free radicals which can exhaust antioxidant defenses thus leading to the oxidative damage to membranes and enhanced susceptibility to LPO (Giugliano et al., 1996). Serum enzymes such as ALT, AST, and ALP are used to evaluate hepatic disorders. In the present study, STZ caused an increase in activity of these enzymes. This may refer to the membrane permeability that was altered due to active or cholestatic hepatic injuries (Zhang et al., 2010). Alteration of the membrane permeability causes derangement in the transport of metabolites leading to leakage of these enzymes (Mehana et al., 2012). Restoration of the transaminases to their normal levels after treatment with algal extract indicates a revival of the insulin secretion. This is consequently associated with the decline of glucose level and inhibition of LPO (Iweala and Oludare, 2011).

Elevated urea and creatinine levels are considered as significant markers of renal dysfunction from diabetic hyperglycemia (Almdal and Vilstrup, 1988). Our results indicated that levels of the urea and creatinine elevated in STZ induced diabetic rats. This was consistent with Ronco et al. (2010) who suggested that the abnormally high levels of urea and creatinine were related to the impaired kidney function. Moreover, it was demonstrated that there was a positive correlation between hyperglycemia and the development of nephropathy (Ceriello et al., 2000). In 2008, Punithavathi et al. postulated that elevation 
of these parameters may be associated with the metabolic abnormalities in gluconeogenesis and greater protein catabolism in diabetic rats. Level of TP decreased in STZ induced diabetes. These findings were supported by Bhargavi et al. (2015) who reported that the reduction in TP might refer to the stimulated conversion of glycogenic amino acids to carbon dioxide and water. The $N$. oculata algal extract prevented negative impact on kidney function in STZ induced diabetes. This may be attributable to the presence of the polysaccharides and fatty acids which may aid in regulating nitrogen compounds in endocrine metabolism (Nuno et al., 2013).

It is well known that the lipid profile appears to be a vital factor in the development of atherosclerosis (Chattopadhyay and Bandyopadhyay, 2005). During the present study, STZ induced diabetes exhibited dyslipidemia through an elevation in total cholesterol, T.Gs, LDL-c and hence decline in HDL-c. This was in accordance with many previous studies (Yadav et al., 2008). This might be attributed to several biochemical mechanisms represented by activation of the hormone-sensitive lipase which facilitate mobilization of fatty acids from T.Gs in adipocytes (Cullen et al., 1999) and/or activation of the lipoprotein lipase which facilitates hydrolysis of T.Gs in endothelial cells (Kondo et al., 2007). The N. oculata algal extract exerted its role in lowering cholesterol and T.Gs levels due to the presence of polysaccharides which play role in reductions in the intestinal absorption (Niewold et al., 2012). Moreover, the algal extract decreased the LDL-c and increased HDL-c. This may refer to the presence of the eicosapentaenoic and docosahexaenoic fatty acids which aid in reducing LDL-c and hence inducing HDL-c (Komprda, 2012). The activity of the serum CPK used as a sensitive indicator in the early stage of myocardial ischemia, while $\mathrm{LDH}$ is roughly proportional to extent of the myocardial tissue injury (Chatterjea and Shinde, 2002).

In the present experiment, STZ injection resulted in a significant increase in CPK and LDH activities. These findings were supported by Alnahdi (2012) who reported that levels of these enzymes in STZ-induced diabetic rats. This may be due to the infarcted myocardium occurred as a result of STZ metabolism (Hamm et al., 1992). Restoration of these enzymes to their normalcy after treatment with the $N$. oculata algal extract may be due to presence polyphenols and the natural antioxidants which preserve the integrity of the tissue. In the current study, STZ caused elevation of the LPO product in pancreas tissue of diabetic rats. This might be due to the effect of the ROS which generated as a result of depletion of the endogenous antioxidant enzymes through glycation of these enzymes at persistently elevated glucose level (Maritim et al., 2003). Subsequently, this leads to an increase in peroxidation reaction (Koo et al., 2001).

The $N$. oculata algal extract scavenging activities against oxidative stress and hence lowered the LPO level. Furthermore, the algal extract exhibited the reducing power which may serve as a significant reflection of the antioxidant activity (Oktay et al., 2003). Subsequently, the compounds exhibit the power to reduce the oxidized intermediates during the peroxidation processes. Therefore, they can act as primary and secondary antioxidants (Chanda and Dave, 2009). STZ has been shown to induce production of the free radicals which cause tissue injury. The pancreas is especially susceptible to be damaged by STZ due to its ability to induce the generation of the free radicals which attack tissue and hence cause tissue injury (Basha and Subramanian, 2011). Based on recent studies carried out by El-Feky et al. (2017), this N. oculata algal extract is rich in various phenolics, chlorophylls, and carotenoids. Moreover, the chromatographic analysis identified presence of flavonoids, pyrogallol, and catechine in addition to the presence of four phenolic compounds (cinnamic acid, p-coumaric acid, p-hydroxybenzoic acid and gallic acid).

In the current study, STZ caused histopathological alterations in the pancreatic tissue. This was in accordance with Higdon et al. (2001) who reported that STZ caused inflammatory changes in pancreatic islets of diabetic rats. Consequently, this leads to atrophy in islands of the Langerhans cells associated with vacuolation of islet cells. This might be due to the destruction of $\beta$-cells and hence decrease in a number of the pancreatic islets. The $N$. oculata algal extract may exhibit antioxidant activity and protect the pancreas from the free radicals attack due to the presence of the active components which are characterized by the scavenging properties and the ability to decrease the production of the free radicals (Selvendran, 2013).

The current study revealed that the alterations in the native electrophoretic protein and lipoprotein patterns in the pancreas of STZ induced diabetic rats may refer to depletion of the antioxidant defenses and accumulation of products of the oxidative stress. This leads to damage to these biological macromolecules (Blasiak et al., 2004). Also, these electrophoretic alterations may occur as a result of nonenzymatic glycation of the native proteins through reaction of sugar with the protein portions (Kennedy and Baynes, 1984). Moreover, the glycation process causes a decrease in the biological role of the chaperone which is responsible for the protein folding (Hook and Harding, 2002). The activity of the antioxidant enzymes is tissue dependent and varies from tissue to tissue. The changes in the activity of the antioxidants in diabetic rats might be attributable to alterations in the metabolic pathways or degeneration of the protein contents as a result of attacking the free radicals (Ramanathan et al., 1999). During the present study, the STZ caused alterations in the different electrophoretic isoenzymes. This might refer to the glycation process which inhibits enzyme activity (Hook and Harding, 1998). Furthermore, Al-Enazi (2014) supported the findings that STZ caused alterations in the electrophoretic CAT and POX patterns due to glycation of these enzymes. The $\alpha$-amylase catalyzes the degradation of the dietary carbohydrates to oligosaccharides and disaccharides through hydrolysis of $\alpha$ - $(1,4)$-D-glycosidic linkages of starch and other glucose polymers. It has been looked at as potential targets for diabetes (Najafian et al., 2011). The $\alpha$-amylase was represented by only one thick band in STZ induced diabetes. This may refer to its effective role in glucose hydrolysis. Moreover, it may refer to changes in amylase protein level in parallel to changes in amylase mRNA level (Kim et al., 1990) or due to the abnormal efficiency of the acinar pancreatic cells to biosynthesize this enzyme (Kamarýt et al., 1993). During our experiment, it was noticed that the $\alpha$-EST was represented by only one band in STZ induced diabetic rats. Also, STZ caused abnormalities in number and arrangement of bands of the $\beta$-EST pattern. This may refer to the binding of the esterase to sugar or sugar phosphate during the glycation process. This leads to the protein cross-linking, aggregation or fragmentation and hence enzyme alterations (Yan and Harding, 
2005). The $N$. oculata algal extract minimized the alterations induced by STZ injection in the different electrophoretic patterns. This may refer to the presence of various active phytoconstituents with antioxidant efficiencies, such as carotenoids, polyunsaturated fatty acids and polysaccharides (Holtin et al., 2009). In addition, the presence of the phenolic compounds is considered as part of a complex defense mechanism against a wide range of stressors and thus accumulates in response to these adverse factors (Dixon and Palva, 1995). The anti-glycating may refer to the presence of ellagic acid (Muthenna et al., 2012), flavonoids, tannic acid and gallic acid (Obrenovich et al., 2010). Walter et al. (2010) emphasized that these polyphenols exhibit the anti-glycating activity through other mechanisms irrespective of glycation inhibition.

During the current experiment, STZ enhanced the DNA fragmentation in pancreas tissue. This was in agreement with Morgan et al. (1994) and supported by Kroncke et al. (1995) who documented that STZ is a donor of the nitric oxide which has been found to bring about the destruction of the pancreatic islet cells. This active molecule contributes to STZ-induced DNA damage and exhibited cytotoxicity due to the formation of peroxynitrite as a result of the interaction of nitric oxide with superoxide anion. The $N$. oculata algal extract exhibited protection against DNA injuries associated with oxidative stress. This may refer to the presence of the bioactive peptides in addition to the natural effective antioxidants (Kim et al., 2012).

\section{CONCLUSIONS}

In this study, it was observed that the $N$. oculata algal extract restored all the biochemical measurements changed in STZ induced diabetes to normalcy. Furthermore, it lowered the LPO level and hence minimized the histopathological alterations occurred in pancreas tissue as a result of STZ effect. It decreased the qualitative mutagenicity in electrophoretic protein, lipoprotein patterns and isoenzymes ( $\alpha$-amylase, $\alpha-, \beta$-EST, CAT, and POX) in pancreas tissue through hiding the abnormal bands and restoring the normal ones. Also, it lowered the quantitative mutation through decreasing quantity of the bands which expressed severely in diabetic rats. Moreover, it maintained the integrity of the genomic DNA which cleaved by STZ giving several unique bands.

\section{CONFLICT OF INTEREST}

The authors declare no potential conflicts of interest with respect to the research, authorship and/or publication of this article.

\section{ACKNOWLEDGMENTS}

The authors thank members of the Algal Biotechnology Unit, National Research Centre, Dokki, Giza, Egypt. Also, they thank Prof. Dr. Adel M.B. Kholoussy, Pathology Department, Faculty of Veterinary Medicine, Cairo University, Egypt for his role in carrying out the histopathological examination.

\section{REFERENCES}

Ahmad A, Maheshwari V, Ahmad A, Saleem R, Ahmad R. Observation of esterase-like-albumin activity during N'-nitrosodimethyl amine induced hepatic fibrosis in a mammalian model. Maced J Med Sci, 2012; 5(1):55-61.

Al-Enazi MM. Combined Therapy of Rutin and Silymarin has More Protective Effects on Streptozotocin-Induced Oxidative Stress in
Rats. Journal of Applied Pharmaceutical Science, 2014; 4(01):021-028.

Almdal TP, Vilstrup H. Strict insulin therapy normalises organ nitrogen contents and the capacity of urea nitrogen synthesis in experimental diabetes in rats. Diabetologia, 1988; 31(2):114-118.

Alnahdi HS. Effect of Rosmarinus Officinalis Extract on some Cardiac Enzymes of Streptozotocin-induced Diabetic Rats. Journal of Health Sciences, 2012; 2(4):33-7.

Archana S, Rashmi N, Khemani LD. Hypoglycemic effect of Hibiscus rosasinensis L. leaf extract in glucose and streptozotocin induced hypoglycemic rats. Indian J Ex Biol, 2001; 39(3):284-286.

Bailey CJ, Flatt PR. 1986. Animal Models of Diabetes. In: Recent Advances in Diabetes II, Nattras, M. (Ed.). Churchill Livingstone, Edinburg, UK. pp 71-89.

Baker CMA, Manwell C. Heterozygosity of the sheep: Polymorphism of "malic enzyme", isocitrate dehydrogenase $\left(\mathrm{NADP}^{+}\right)$, catalase and esterase. Aust. J. Biol. Sci, 1977; 30(1-2):127-40.

Banchroft JD, Stevens A, Turner DR. 1996. Theory and Practice of Histological Techniques. Fourth Ed. Churchil Livingstone, New York, London, San Francisco, Tokyo.

Barker DL, Hansen MS, Faruqi AF, Giannola D, Irsula OR, Lasken RS, Latterich M, Makarov V, Oliphant A, Pinter JH. Two Methods of Whole-Genome Amplification Enable Accurate Genotyping Across a 2320-SNP Linkage Panel. Genome Res, 2004; 14(5):901-907.

Basha S, Subramanian S. Biochemical evaluation of antidiabetic and antioxidant potentials of annana squamosa leaves extracts studied in streptozocin induced diabetic rats. IJPSR, 2011; 2(3):643-655.

Bhargavi G, Josthna P, Naidu CV. Changes in serum biochemical parameters and lipid profile in normal and STZ induced diabetic rats with the administration of ethanolic extract of polyalthia cerasoides stem bark. International Research Journal of Pharmacy, 2015; 6(2):153-156.

Blasiak J, Arabski M, Krupa R, Wozniak K, Zadrozny M, Kasznicki J, Zurawskac M, Drzewoski J. DNA damage and repair in type 2 diabetes mellitus. Mutation Research, 2004; 554(1-2):297-304.

Bradford MM. A rapid and sensitive method for the quantitation of microgram quantities of protein utilizing the principle of protein-dye binding. Anal Biochem, 1976; 72(1-2):248-254.

Brand-Williams W, Cuvelier ME, Berset C. Use of a free radical method to evaluate antioxidant activity. Lebenson Wiss Technol, 1995; 28(1):25-30.

Brenna O, Qvigstad G, Brenna E, Waldum HL. Cytotoxicity of streptozotocin on neuroendocrine cells of the pancreas and the gut. Dig Dis Sci, 2003; 48(5):906-910.

Ceriello A, Morocutti A, Franceschina M, Quagliaro L, Moro M, Damante G, Viberti GC. Defective intracellular Antioxidant Enzyme Production in Type 1 Diabetic Patients with Nephropathy. Am Diabetes Assoc, 2000; 49(12):2170-2177.

Chanda S, Dave R. In vitro models for antioxidant activity evaluation and some medicinal plants possessing antioxidant properties: An overview. African Journal of Microbiology Research, 2009; 3(13):981-996.

Chatterjea MN, Shinde R. 2002. Serum enzymes in heart diseases. In Chatterjea and Shinde (ed) Textbook of Medical Biochemistry ( $5^{\text {th }}$ ed.) Jappe brothers, New Delhi, Med. Publ. Ltd. pp 555-557.

Chattopadhyay RR, Bandyopadhyay M. Effect of Azadirachta Indica on serum lipid profile changes in normal and Streptozotocin induced diabetic rats. Afr J Biomed Res, 2005; 8:101-104.

Cullen P, Eckardstein A, Souris S, Schulte H, Assmann G. Dyslipidaemia and cardiovascular risk in diabetes. Diabetes Obes Metab, 1999; 1:189-198.

Darwesh OM, Moawad H, Barakat OS, Abd El-Rahim WM. Bioremediation of Textile Reactive Blue Azo Dye Residues using Nanobiotechnology Approaches. Research Journal of Pharmaceutical, Biological and Chemical Sciences, 2015; 6(1):1202-1211.

Dixon RA, Palva N. Stress-induced phenylpropanoid metabolism. Plant Cell, 1995; 7(7):1085-1097.

Dommels YEM, Butts CA, Zhu S, Davy M, Martell S, Hedderley D, Barnett MPG, McNabb WC, Roy NC. Characterization of intestinal 
inflammation and identification of related gene expression changes in mdr1a(-/-) mice. Genes Nutr, 2007; 2(2):209-223.

Elder C. Ayurveda for diabetes mellitus: a review of the biomedical literature. Alter Ther Health Med, 2004; 10(1):44-50.

El-Feky AM, Aboulthana WM, El-Sayed AB, Ibrahim NE. Chemical and therapeutic study of Nannochloropsis oculata on spleen of streptozotocin induced diabetes in rats. Der Pharma Chemica, 2017; 9(18):36-43.

Enwereuzoh UO, Onyeagoro GN. A Novel Aeration Method for the Preparation of Algae (Dunaliella Salina) Biomass for Biofuel Production. American Journal of Engineering Research (AJER), 2014; 3(9):209-214.

Giugliano D, Ceriello A, Paolisso G. Oxidative stress and diabetic vascular complications. Diabetes Care, 1996; 19(3):257-267.

Guariguata L, Whiting D, Weil C, Unwin M. The international diabetes federation diabetes atlas methodology for estimating global and national prevalence of diabetes in adults. Diabetes Res Clin Pract, 2011; 94(3):322-332.

Hames BD. 1990. One-dimensional polyacrylamide gel electrophoresis. In: Gel electrophoresis of proteins: BD Hames BD, Rickwood D, $2^{\text {nd }}$ ed. NY: Oxford university press. pp 1-147.

Hamidi N, Yanuhar U, Wardana ING. Potential and properties of marine microalgae Nannochloropsis oculata as biomass fuel feedstock. International Journal of Energy and Environmental Engineering, 2014; 5(4):279-290.

Hamm CW, Ravkilde J, Gerhardt W, Jorgensen P, Peheim P. The prognostic value of serum troponin $\mathrm{T}$ in unstable angina. $\mathrm{N}$ Engl $\mathrm{J}$ Med, 1992; 327(3):146-150

Higdon HL, Parnell PG, Hill JE, Spitzer JC. Streptozocininduced pancreatic islet destruction in beef cows. Vet Pathol, 2001; 38(6):715-720.

Holtin K, Kuehnle M, Rehbein J, Schuler P, Nicholson G, Albert $\mathrm{K}$. Determination of astaxanthin and astaxanthin esters in the microalgae Haematococcus pluvialis by LC-(APCI) MS and characterization of predominant carotenoid isomers by NMR spectroscopy. Analytical and bioanalytical chemistry, 2009; 395(6):1613-1622.

Hook DWA, Harding JJ. Protection of enzyme by alphacrystallin acting as a molecular chaperone. Int J Biol Macromol, 1998; 22(3-4):295-306.

Hook DWA, Harding JJ. The effect of modification of alphacrystallin by prednisolone-21-hemisuccinate and fructose 6-phosphate on chaperone activity. Dev Ophthalmol, 2002; 35:150-160.

Iweala EJ, Oludare FD. Hypoglycemic effect, biochemical and histological changes of spondias mombin linn, and painari polyandra benth. Seeds Ethanolic extracts in alloxan induced diabetic rats. Journal of Pharmacology and Toxicology, 2011; 6(2):101-112.

Jain SK, Rains JL, Croad JL. Effect of chromium niacinate and chromium picolinate supplementation on lipid peroxidation, TNF-a, IL-6, CRP, glycated hemoglobin, triglycerides, and cholesterol levels in blood of streptozotocin treated diabetic rats. Free Radical Biology and Medicine, 2007; 43(8):1124-1131.

Kamarýt J, Stejskal J, Osicková L, Mrskos A, Pribylová H, Coupek P. Urinary amylase isoenzymes and amylase polymorphism variants in families with diabetes mellitus type 1. Eur J Clin Chem Clin Biochem, 1993; 31(11):739-742.

Kar A, Choudhary BK, Bandyopadhyay NG. Preliminary studies on the inorganic constituents of some indigenous hypoglycaemic herbs on oral glucose tolerance test. J Ethnopharmacol, 1999; 64(2):179-184.

Kasiviswanath R, Ramesh A, Kumar KE. Hypoglycemic and antihyperglycemic effect of Gmelina asiatica LINN. in normal and in alloxan induced diabetic rats. Biol Pharm Bull, 2005; 28(4):729-732.

Kennedy L, Baynes JW. Non-enzymatic glycosilation and the chronic complications of diabetes: An Overview. Diabetologia, 1984; 26(2):93-98.

Kent M, Welladsen HM, Mangott A, Li Y. Nutritional Evaluation of Australian Microalgae as Potential Human Health Supplements. PLoS
ONE, 2015; 10(2):e0118985.

Kim JD, Kang SM, Seo BI, Choi HY, Choi HS, Ku SK. Antidiabetic activity of SMK001, a poly herbal formula in streptozotocin induced diabetic rats: therapeutic study. Biol Pharm Bull, 2006; 29(3):477482.

Kim K, Cha S, Kim E, Kang M, Yang H, Kim M, Yang H, Roh SW, Jung W, Heo S, Kim D, Jeon Y, Oda T. Neuroprotective effects of Nannochloropsis oculata against AAPH-induced oxidative DNA damage in HT22 cells. International Journal of Pharmacology, 2012; 8(6):527-534.

Kim SK, Cuzzort LM, McKean RK, Allen ED. Effects of diabetes and insulin on alpha-amylase messenger RNA levels in rat parotid glands. J Dent Res, 1990; 69(8):1500-1504.

Komprda T. Eicosapentaenoic and docosahexaenoic acids as inflammation-modulating and lipid homeostasis influencing nutraceuticals: A review. Journal of Functional Foods, 2012; 4(1):25-38.

Kondo HU, Kiyose C, Ohmori R, Saito H, Tagughi C, Kishimoto Y. Improves Lipoprotein Metabolism in Humans. J Nutr Sci Vitaminol, 2007; 53(4):345-348

Koo JR, Oviesi F, Vaziri ND. Antioxidant therapy potentiates anthihypertensive action of insulin in diabetes rats. Am J Hipertens, 2001; 14:53-55.

Kroncke KD, Fehsel K, Sommer A, Rodriguez ML, KolbBachofen V. Nitric oxide generation during cellular metabolization of the diabetogenic N-methyl-N-nitroso-urea streptozotozin contributes to islet cell DNA damage. Biol Chem Hoppe-Seyler, 1995; 376(3):179-185.

Kumar R, Arora V, Ram V, Bhandari A, Vyas P. Hypoglycemic and hypolipidemic effect of Allopolyherbal formulations in streptozotocin induced diabetes mellitus in rats. International Journal of Diabetes Mellitus, $2015 ; 3(1): 40-45$

Loew D, Kaszkin M. Approaching the problem of bioequivalence of Herbal Medicinal Products. Phytother Res, 2002; 16(8):705-711.

Mahfouz MK. Curcumin improves insulin sensitivity and ameliorates serum pro-inflammatory cytokines levels in diabetes rat model irrespective of type of diabetes. J Am Sci, 2011; 7(6):794-299.

Manoj K. Mercury, copper and cadmium induced charges in the total protein levels in muscles tissues of edible estuarine fish Boleopthalums desssumari. Cuv J Env Bio, 1999; 20:231-234.

Maritim AC, Sandres RA, Watkins JB. Diabetes, oxidative stress, and antioxidants: a review. J Biochem Mol Toxicol, 2003; 17(1):24-38

Mehana EE, Meki AR, Fazili KM. Ameliorated effects of green tea extract on lead induced liver toxicity in rats. Experimental and Toxicologic Pathology, 2012; 64(4):291-295.

Morgan NG, Cable HC, Newcombe NR, Williams GT. Treatment of cultured pancreatic B-cells with streptozotocin induces cell death by apoptosis. Biosci Rep, 1994; 14(5):243-250.

Mosmann T. Rapid colorimetric assays for cellular growth and survival: Application to proliferation and cytotoxicity assays. J Immunol Methods, 1983; 65(1-2):55-63.

Mutalik S, Sulochana B, Chetana M, Udupa N, Devi VP. Preliminary studies on acute and subacute toxicity of an antidiabetic herbal preparation-Dianex. Indian J Exp Biol, 2003; 41(4):316-20.

Muthenna P, Akileshwari C, Reddy GB. Ellagic acid, a new antiglycating agent: Its inhibition of $\mathrm{N} \epsilon-($ carboxymethyl)lysine. Biochem J, 2012; 442(1):221-230.

Mythili MD, Vyas R, Akila G, Gunasekaran S. Effect of streptozotocin on the ultrastructure of rat pancreatic islets. Microse Res Tech, 2004; 63(5):274-281.

Najafian M, Ebrahim-Habibi A, Yaghmaei P, Parivar K, Larijani B. Core structure of flavonoids precursor as an antihyperglycemic and antihyperlipidemic agent: An in vivo study in rats. Acta Biochimica Polonica, 2010; 57(4):553-560.

Najafian M, Jahromi MZ, Nowroznejhad MJ, Khajeaian P, Kargar MM, Sadeghi M, Arasteh A. Phloridzin reduces blood glucose levels and improves lipids metabolism in streptozotocin-induced diabetic rats. Mol Biol Rep, 2011; 1(1):1-8.

Nei M, Li WS. Mathematical model for studing genetic variation 
in terms of restriction endonuclease. Proc Natl Acad Sci., USA, 1979; 76(10):5269-5273.

Niewold TA, Schroyen M, Geens MG, Verhelst RSB, Courtin CM. Dietary inclusion of arabinoxylan oligosaccharides (AXOS) down regulates mucosal responses to a bacterial challenge in piglet model. Journal of Functional Foods, 2012; 4(3):626-635.

Noor A, Gunasekaran S, Manickam AS, Vijayalakshmi MA. Antidiabetic activity of Aloe vera and histology of organs in streptozotocin -induced diabetic rats. Curr Sci, 2008; 94(8):1070-1076.

Nuno K, Villarruel-Lopez A, Puebla-Perez AM, RomeroVelarde E, Puebla-Mora AG, Ascencio F. Effects of the marine microalgae Isochrysis galbana and Nannochloropsis oculata in diabetic rats. Journal of Functional Foods, 2013; 5(1):106 -115.

Obrenovich ME, Nair NG, Beyaz A, Aliev G, Reddy VP. The role of polyphenolic antioxidants in health, disease, and aging. Rejuvenation Res, 2010; 13(6):631-643.

Ohkawa H, Ohishi N, Nagi K. Assay of lipid peroxides in anima tissue by thiobarbituric acid reaction. Anal Biochem, 1979; 95(2):351-358.

Oktay M, Gulcin I, Kufrevioglu OI. Determination of in vitro antioxidant activity of fennel (Foeniculum vulgare) seed extracts. Lebensum Wiss U Technol, 2003; 36(2):263-271.

Oyaizu M. Studies on product of browning reaction prepared from glucose amine. Japanese Journal of nutrition, 1986; 44(6):307-315.

Paget GE, Barnes JM. 1964. Toxicity tests. In: Laurance DR, Bacharach AL, editors. Evaluation of Drug Activities: Pharmacometrics, Vol 1. New York: Academic Press 135-65.

Patil A, Nirmal S, Pattan S, Tambe V, Tare M. (2012). Antidiabetic effect of polyherbal combinations in STZ induced diabetes involve inhibition of $\alpha$-amylase and $\alpha$-glucosidase with amelioration of lipid profile. Phytopharmacology, 2012; 2(1):46-57.

Prasad SK, Alka K, Qureshi TN. Antidiabetic activity of some herbal plants in streptozotocin induced diabetic albino rats. Pak J Nutr, 2009; 8(5):551-557.

Punithavathi VR, Anuthama R, Prince PS. Combined treatment with naringin and vitamin $\mathrm{C}$ ameliorates streptozotocin-induced diabetes in male wistar rats. J Appl Toxicol, 2008; 28(6):806-813.

Ramanathan M, Jaiswal AK, Bhattacharya SK. Superoxide dismutase, catalase and glutathione peroxidase activities in the brain of streptozotocin induced diabetic rats. Indian Journal of Experimental Biology, 1999; 37(2):182-183.

Rammesmayer G, Praznik W. Fast and sensitive simultaneous staining method of Q-enzyme, $\alpha$-amylase, R-enzyme, phosphorylase and soluble starch synthase separated by starch: polyacrylamide gel electrophoresis. J Chromatogr, 1992; 623(2):399-402.

Rapley R. 1998. Polymerase chain reaction: Molecular Biomethods Handbook. In: Rapley R, Walker JM, ed. Humana, Totowa, NJ 305-25.

Rescigno A, Sanjust E, Montanari L, Sollai F, Soddu G, Rinaldi AC, Oliva S, Rinaldi A. Detection of laccase, peroxidase and polyphenol oxidase on a single polyacrylamide gel electrophoresis. Anal Lett, 1997; 30(12):2211-2220

Ridker PM. Clinical application of C-reactive protein for cardiovascular disease detection and prevention. Circulation, 2003; 107(3):363-369.

Ronco C, Grammaticopoulos S, Rosner M, Decal M, Soni S, Lentini P, Piccinni P. Oliguria, creatinine and other biomarkers of acute kidney injury. Contributions Nephrol, 2010; 164:118-127.

Sanjeewa KKA, Fernando IPS, Samarakoon KW, Lakmal HHC, Kim E, Kwon O, Dilshara MG, Lee J, Jeon Y. Anti-inflammatory and anti-cancer activities of sterol rich fraction of cultured marine microalga Nannochloropsis oculata. Algae, 2016; 31(3):277-287.

Scholz MJ, Weiss TL, Jinkerson RE, Jing J, Roth R, Goodenough U, Posewitz MC, Gerken HG. Ultrastructure and composition of the Nannochloropsis gaditana cell wall. Eukaryot Cell, 2014; 13(11):14501464.

Schwartsmann G, Brondani da Rocha A, Berlinck RG, Jimeno $\mathrm{J}$. Marine organisms as a source of new anticancer agents. Lancet Oncol, 2001; 2(4):221-225.

Selvendran M. Studies on antimicrobial compounds from selected marine phytoplanktons. Int J Pharm Bio Sci, 2013; 4(2):876-888.

Siciliano MJ, Shaw CR. 1976. Separation and visualization of enzymes on gels, in Chromatographic and Electrophoretic Techniques, Vol. 2, Zone Electrophoresis. In: Smith I, Ed. Heinemann, London. 185.

Singleton VL, Rossi JA. Colorimetry of total phenolics with phosphomolybdic phosphotungstic acid reagents. Am J Enol Vitic, 1965; 16(3):144-158

Subramaniam HN, Chaubal KA. Evaluation of intracellular lipids by standardized staining with a Sudan black B fraction. J Biochem Biophys Methods, 1990; 21(1):9-16.

Venkataramana Sandhya GV, Rani PN, Moorthy PS. Impact of Malathion on the biochemical parameters of Gobiid fish. Glossobius gigris (Ham). J Environ Biol, 2006; 27(1):119-122.

Walter A, Etienne-Selloum N, Brasse D, Khallouf H, Bronner C, Rio MC, Beretz A, Schini-Kerth VB. Intake of grape-derived polyphenols reduces $\mathrm{C} 26$ tumor growth by inhibiting angiogenesis and inducing apoptosis. FASEB J, 2010; 24(9):3360-3369.

WHO Expert. Committee on Diabetes Mellitus Technical Report Series 646, Geneva and World Health Oraganisation. 1980.

Yadav JP, Saini S, Kalia AN, Dangi AS. Hypoglycemic and hypolipidemic activity of Ethanolic extract of Salvadora oleoides in normal and alloxan-induced diabetic rats. Ind J Pharmacol, 2008; 40(1):23-27.

Yan H, Harding JJ. Carnosine protects against the inactivation of esterase induced by glycation and a steroid. Biochimica et Biophysica Acta, 2005; 1741(1-2):120-126.

Yanuhar U, Nurdiani R, Hertika AMS. Potency of Nannochloropsis oculata as Antibacterial, Antioxidant and Antiviral on Humpback Grouper Infected by Vibrio alginolyticus and Viral Nervous Necrotic. Journal of Food Science and Engineering, 2011; 1(5):323-330.

Zhang Y, Lu X, Hong J, Chao M, Gu W, Wang W, Ning G. Positive correlations of liver enzymes with metabolic syndrome including insulin resistance in newly diagnosed type 2 diabetes mellitus. Endocrine, 2010; 38(2):181-187.

How to cite this article:

Aboulthana WM, El-Feky AM, Ibrahim NE, Sahu RK, ElSayed AEB. Evaluation of the Pancreatoprotective Effect of Nannochloropsis oculata Extract against Streptozotocin-Induced Diabetes in Rats. J App Pharm Sci, 2018; 8(06): 046-058. 